\title{
Quantification of $\operatorname{PrP}^{\mathrm{C}}$ in bovine peripheral tissues: Analysis in wild-type and $\operatorname{PrP}^{\mathrm{C}}$-deficient cattle
}

\author{
SHIN-ICHI KOBAYASHI ${ }^{1 *}$, YASUHISA ANO ${ }^{1 *}$, AKIKAZU SAKUDO ${ }^{3}$, MASAYOSHI YUKAWA $^{4}$, \\ KATSUAKI SUGIURA $^{5}$, NOBORU MANABE ${ }^{1,2}$, HIROYUKI NAKAYAMA ${ }^{1,2}$ and TAKASHI ONODERA ${ }^{1,2}$ \\ ${ }^{1}$ School of Agricultural and Life Sciences, ${ }^{2}$ Research Center for Food Safety, The University of Tokyo, \\ Bunkyo-ku, Tokyo 113-8657; ${ }^{3}$ Research Institute for Microbial Diseases, Osaka University, Yamadaoka, \\ Suita, Osaka 565-0871; ${ }^{4}$ Laboratory of Biomedical Science, Department of Veterinary Medicine, \\ College of Biosource Sciences, Nihon University, Kameino 1866, Fujisawa, Kanagawa 252-8510; \\ ${ }^{5}$ Food and Agricultural Materials Inspection Center, Saitama, Saitama 330-9731, Japan
}

Received January 27, 2009; Accepted April 1, 2009

DOI: 10.3892/mmr_00000137

\begin{abstract}
Cellular $\operatorname{PrP}\left(\mathrm{PrP}^{\mathrm{C}}\right)$ is necessary for bovine spongiform encephalopathy (BSE) infection. The purpose of the present experiment was the quantification of $\mathrm{PrP}^{\mathrm{C}}$ in peripheral tissues to assess the risk of BSE infection from these tissues. The tissue distribution of $\operatorname{PrP}^{\mathrm{C}}$ was examined by a sandwich enzyme-linked immunosorbent assay (sELISA) and histochemical analysis. $\operatorname{PrP}^{\mathrm{C}}$-deficient cows were used as a negative control. The sELISA revealed that the brain contained the highest $\mathrm{PrP}^{\mathrm{C}}$ content (10.7 $\mu \mathrm{g} / \mathrm{g}$ tissue), while other organs/ tissues harbored lower amounts, in decreasing order as follows: longissimus capitis muscle, iliocostalis thoracis muscle, splenius muscle, biceps femoris muscle, triceps brachii muscle, longissimus thoracis muscle, ileum, jejunum, duodenum, colon, cecum, apex linguae, omotransversarius muscle, posterior part of the corpus linguae, anterior part of the corpus linguae and radix linguae (5.2- to 31-fold less $\operatorname{PrP}^{\mathrm{C}}$ than the brain). In the tissue/organs of $\mathrm{PrP}$-deficient cows, $\operatorname{PrP}^{\mathrm{C}}$ levels were under the limit of detection. Histochemical analysis showed that $\operatorname{PrP}^{\mathrm{C}}$ was expressed in nerve cells in intestinal tissues. The presence of $\mathrm{PrP}^{\mathrm{C}}$ in the bovine tongue, skeletal muscles and intestines raises the possibility of $\mathrm{PrP}^{\mathrm{Sc}}$ accumulation in these tissues, indicating that these organs/tissues may serve as potential sources of BSE infection.
\end{abstract}

\section{Introduction}

The cellular isoform of prion protein $\left(\mathrm{PrP}^{\mathrm{C}}\right)$, a glycoprotein with a glycosylphosphatidyl inositol (GPI) anchor, plays a

Correspondence to: Dr Takashi Onodera, School of Agricultural and Life Sciences, The University of Tokyo, Bunkyo-ku, Tokyo 113-8657, Japan

E-mail: aonoder@mail.ecc.u-tokyo.ac.jp

*Contributed equally

Key words: prion protein, sandwich ELISA, muscle, risk assessment, intestine, prion protein-deficient cow pivotal role in the infection of transmissible spongiform encephalopathies (TSEs). These comprise a family of neurodegenerative disorders affecting both humans and animals. TSEs include bovine spongiform encephalopathy (BSE), transmissible mink encephalopathy (TME), feline spongiform encephalopathy (FSE), sheep scrapie, iatrogenic CreutzfeldtJakob disease (CJD), sporadic CJD (sCJD) and variant CJD (vCJD). TSEs are characterized by the accumulation of a modified form or a protease-resistant form $\left(\mathrm{PrP}^{\mathrm{Sc}}\right)$, derived from $\mathrm{PrP}^{\mathrm{C}}$. Although the conversion of host-encoded $\mathrm{PrP}^{\mathrm{C}}$ is crucial for disease transmission and $\operatorname{PrP}^{\mathrm{Sc}}$ formation $(1,2)$, the mechanism(s) of prion transmission remains unresolved. Furthermore, $\operatorname{PrP}^{\mathrm{Sc}}$ accumulation and $\operatorname{PrP}^{\mathrm{C}}$ deficiency induced by prion infection in the brain are presumed to be causative factors of prion disease (3). One emerging hypothesis advocates that the abovementioned conversion phenomenon occurs at the site where the infectious agent binds with $\operatorname{PrP}^{\mathrm{C}}$. In cattle, apart from accumulating preferentially in specified-risk materials (SRM) such as the brain and spinal cord, $\operatorname{PrP}^{\mathrm{Sc}}$ was also deposited in the ischiadic nerve, tibial nerve and adrenal gland of a 94-month-old BSE-positive (11th) case in Japan (7). Thus, $\mathrm{PrP}^{\mathrm{Sc}}$ has the potential to accumulate in peripheral tissues as well as in SRM. PrP ${ }^{\mathrm{Sc}}$ was recently detected in the muscles of sheep $(4,5)$, mice infected with scrapie (6), BSE or vCJD (8), hamsters infected with scrapie $(9-11)$, TME $(9,12)$ or BSE (8), and humans infected with SCJD $(13,14)$. To assess the risk of $\mathrm{PrP}^{\mathrm{Sc}}$ accumulation in peripheral tissues, it is important to understand the distribution and expression levels of $\mathrm{PrP}^{\mathrm{C}}$ in these tissues. To date, although studies have been performed in rodents (15-18), sheep (19,20), cervidae (21) and humans (22), $\mathrm{PrP}^{\mathrm{c}}$ levels in the peripheral tissues of cattle, which are regarded as transmission carriers of vCJD in humans, remain to be determined.

In this study, the anti-prion protein (PrP) monoclonal antibodies (mAbs) T2 and T17 (purified from hybridoma supernatants) were labeled with horseradish peroxidase (HRP) before being subjected to a novel sandwich enzyme-linked immunosorbent assay (sELISA) established using these mAbs. Quantification of $\operatorname{PrP}^{\mathrm{C}}$ levels in the bovine tongue, skeletal muscles and intestines was carried out by comparison with levels in PrP gene-deficient cows. 


\section{Materials and methods}

Animals and tissue materials. Fifty-nine-month-old and 6-month-old Holstein cattle were housed at the Animal Resource Center, Graduate School of Agriculture and Life Science, the University of Tokyo. All animals were treated in accordance with procedures authorized by the Animal Experiment Committee of the School of Agriculture and Life Science. After the animals were anesthetized with propofol and euthanized by exsanguination, the brain, apex linguae, anterior part of the corpus linguae, posterior part of the corpus linguae, radix linguae, splenius muscle, longissimus capitis muscle, omotransversarius muscle, longissimus thoracis muscle, iliocostalis thoracis muscle, triceps brachii muscle, biceps femoris muscle, colon, duodenum, ileum, jejunum and cecum were isolated. The liver was removed from 59-month old Holestein cattle. The brain of an 8-week-old Syrian hamster (Japan SLC, Inc.) was isolated and used as a reference.

This study also examined and compared each tissue (muscle, ileum and liver) from prion gene-deficient cows $(n=2)$ as a negative control for prion protein, kindly provided by JA ZEN-NOH. The cattle lacking prion protein were produced using methods reported previously (23).

Recombinant bovine PrP. Recombinant bovine PrP (25-241) (Alicon, Schlieren, Switzerland) was used in this study.

Preparation of tissue homogenates. Bovine tissues (from 59-month-old, 8-month-old and prion gene-deficient cows) were homogenized in lysis buffer [phosphate-buffered saline (PBS) containing $0.5 \%$ Nonidet P-40, $0.5 \%$ sodium deoxycholate and $2 \mathrm{mM}$ phenylmethylsulfonyl fluoride] using a bead shocker (FastPrep ${ }^{\circledR}$; Thermo Electron) at $6.5 \mathrm{~m} / \mathrm{sec}$ for $45 \mathrm{sec} \times 2$ for the preparation of $10 \%(\mathrm{w} / \mathrm{v})$ tissue homogenates. The hamster brain was homogenized in lysis buffer using an ultrasonic disintegrator (Sonifier 250; Branson), subjected to centrifugation at $5,000 \mathrm{x}$ g for $5 \mathrm{~min}$ and stored at $-80^{\circ} \mathrm{C}$ until use.

Purification andhorseradishperoxidase-labeling of $m A b s$. The characterization of the anti-PrP mAbs T2 and T17 is shown in Table I. Hybridomas producing T2 and T17 mAbs were grown separately in hybridoma-SFM (serum-free medium; Invitrogen) at $37^{\circ} \mathrm{C}$ in a humidified $5 \% \mathrm{CO}_{2}$ incubator. Cell suspensions were subjected to centrifugation at 1,500 $\mathrm{x} g$ for $5 \mathrm{~min}$ before the supernatants were harvested. The mAbs were isolated from hybridoma supernatants using HiTrap Protein-G (Amersham Biosciences) and a PD-10 column (Amersham Biosciences) in accordance with the manufacturer's instructions. Harvested mAbs were labeled with horseradish peroxidase (HRP) using a Peroxidase-labeling Kit-SH (Dojindo) in accordance with the manufacturer's instructions.

SDS-PAGE. Protein samples were boiled in $2 \mathrm{X}$ SDS gel-loading buffer [90 mM Tris-HCl (pH 6.8), 10\% mercaptoethanol, $2 \%$ SDS, $0.02 \%$ bromophenol blue and $20 \%$ glycerol] for $5 \mathrm{~min}$ before being subjected to electrophoresis on SDS-12\% polyacrylamide gel with molecular weight markers (Full-Range Rainbow $^{\mathrm{TM}}$ Recombinant Protein Molecular Weight Marker RPN800; Amersham Biosciences). The gel was electro-blotted onto a polyvinylidene difluoride(PVDF) membrane (Hybond-P;
Table I. Characterization of the anti-PrP mAbs.

\begin{tabular}{lccc}
\hline mAb & $\begin{array}{c}\text { Immune } \\
\text { animal }\end{array}$ & Immunogen & Epitope \\
\hline $\mathrm{T} 2$ & Mouse & Recombinant mouse PrP (aa121-231) & $132-156$ \\
$\mathrm{~T} 17$ & Mouse & Recombinant mouse PrP (aa121-231) & $174-217$ \\
\hline
\end{tabular}

Amersham Biosciences) for $1 \mathrm{~h}$ at $120 \mathrm{~mA}$. Resolved proteins on the membrane were visualized using Coomassie brilliant blue (CBB) staining.

Western blotting. Electrophoresis of the $10 \%$ tissue homogenate was performed on SDS-12\% polyacrylamide gel before electroblotting onto PVDF membranes using the method described above. The membranes were treated with Block Ace (Dainippon Sumitomo Pharmaceuticals) for $1 \mathrm{~h}$ at room temperature and subsequently incubated for $1 \mathrm{~h}$ at room temperature with $\mathrm{T} 2$ or HRP-labeled T2 (T2-HRP) antibodies ( $1 \mu \mathrm{g} / \mathrm{ml}$ in PBS with $0.1 \%$ Tween-20 or PBS-T). After three washes in PBS-T, the T2-incubated membranes were further incubated with a secondary antibody, peroxidase-labeled anti-mouse IgG (diluted 1:5000 in PBS-T) (Amersham Biosciences) for $1 \mathrm{~h}$ at room temperature. After three washes in PBS-T, the probed proteins were detected with a chemiluminescent substrate $\left(\mathrm{ECL}^{\mathrm{TM}}\right.$ Detection Reagents; Amersham Biosciences) using a luminoimage analyzer (LAS-3000mini; Fujifilm).

Sandwich ELISA. Microtiter plates (Nunc-Immuno ${ }^{\mathrm{TM}}$ Modules; Nunc) were coated with $100 \mu \mathrm{l}$ of purified capture mAbs $(1 \mu \mathrm{g} / \mathrm{ml})$ in $0.1 \mathrm{M}$ carbonate buffer $(\mathrm{pH} 9.5)$ overnight at $4^{\circ} \mathrm{C}$ and washed three times with PBS-T using a Nunc-Immuno ${ }^{\mathrm{TM}}$ Wash 8 (Nunc). The coated plates were then blocked with $200 \mu \mathrm{l}$ of Block Ace (diluted 1:4 in PBS-T) for $1 \mathrm{~h}$ at room temperature, and subsequently rinsed three times with PBS-T. Diluted samples in PBS (100 $\mu \mathrm{l})$ dispersed in 96-well plates were incubated for $1 \mathrm{~h}$ at room temperature. The plates were washed five times with PBS-T prior to treatment with $100 \mu \mathrm{l}$ of HRP-labeled anti-PrP mAbs $(0.5 \mu \mathrm{g} / \mathrm{ml})$ and PBS-T in the wells. After washing with PBS-T, O-phenylenediamine (Sigma) solution was dispensed at $100 \mu \mathrm{l} /$ well. After incubation for $30 \mathrm{~min}$ in the dark, each well was treated with $20 \mu \mathrm{l}$ of $\mathrm{H}_{2} \mathrm{SO}_{4}(6 \mathrm{~N})$, then the absorbance of each well was measured at $490 \mathrm{~nm}$ on a microplate reader (Bio-Rad).

Tissue preparation and immunohistochemistry. Each tissue sample (from a 6-month-old cow) was collected, fixed and embedded in resin (Technovit 8100; Heraeus Kulzer, Wehrheim, Germany) as described previously $(24,25)$. Sections $(4-\mu \mathrm{m})$ were sliced, mounted on silanized glass slides, subjected to immunohistochemistry, and observed using a fluorescence microscope (Olympus, Tokyo, Japan).

To observe distribution in the peripheral nervous system and cellular prion protein in the bovine ileum, sections were reacted with anti-PrP mAb T2 (1:100) or anti-PgP $9.5 \mathrm{pAb}$ (1:100; Abcam, Tokyo, Japan) for $2 \mathrm{~h}$ at $37^{\circ} \mathrm{C}$, then further incubated with Alexa Fluor ${ }^{\circledR} 488$-coupled goat anti-mouse IgG $(\mathrm{H}+\mathrm{L})$ antibody, or with goat anti-rabbit $\mathrm{IgG}(\mathrm{H}+\mathrm{L})$ antibody 
coupled with Alexa Fluor ${ }^{\circledR} 546(5 \mu \mathrm{g} / \mathrm{ml}$; Molecular Probes, Eugene, OR, USA) at room temperature for $30 \mathrm{~min}$. Sections were then counterstained with DAPI.

Calculating the limit of detection for PrP levels. A limit of detection (LD) is defined as an analyte concentration that yields a signal intensity 3-fold the SD and mean intensity of the blank solution. According to Miller and Miller (26), the LD (y) is calculated based on the mean $\left(\mathrm{y}_{\mathrm{B}}\right)$ and $\mathrm{SD}\left(\mathrm{S}_{\mathrm{B}}\right)$ of the signal from the blank control (vehicle signal) as shown in Equation (i). Therefore, the LD is defined if a sample is appropriate for PrP detection. The value of the calculated intercept on the ordinate is used as an estimate of $\mathrm{y}_{\mathrm{B}}$; i.e., the blank signal (26). To estimate $S_{B}$, statistical estimates of random errors on the ordinate $\left[\mathrm{S}_{\mathrm{y} / \mathrm{x}}\right.$; see Equation (ii)] were substituted for $\mathrm{S}_{\mathrm{B}}(26)$. The $\hat{y}_{i}$-values are points on the calculated regression line corresponding to the individual $\mathrm{x}$-values:

$$
\begin{gathered}
y=y_{B}+3 S_{B} \\
S_{y / x}=\left\{\frac{\sum_{i}\left(y_{i}-\hat{y}_{i}\right)^{2}}{n-2}\right\}^{1 / 2}
\end{gathered}
$$

\section{Results}

The isolation and purification of the anti-PrP mAbs T2 and T17 from the supernatants were verified by SDS-PAGE. The bands of heavy- and light-chain mAbs were respectively visualized at 50 and $25 \mathrm{kDa}$ by T2 and T17 antibodies with CBB staining. The purified $\mathrm{mAbs}$ were labeled with HRP using a peroxidaselabeling Kit-SH. The SH-reactive peroxidase in this kit has the maleimide to form a covalent bond with a sulfhydryl group of the reduced IgG form, thus binding 1 to 2 peroxidase molecules per IgG. PrP detection was performed by Western blotting to verify HRP-labeling before analysis with sELISA using the same mAbs. Using combinations of T2 and T7-HRP or T17 and T2-HRP, PrP was detected in a concentrationdependent fashion. However, PrP was not detected by T2-HRP or T17-HRP without any captured $m$ Abs. This finding indicates that the novel sELISA method established in this study can detect PrP specifically. The combination of T2 as a captured $\mathrm{mAb}$ and T17-HRP as an identification $\mathrm{mAb}$ detected PrP with a higher sensitivity than T17 and T2-HRP combined. This is probably attributable to substantially more labeling of T17 than T2 with peroxidase molecules prior to sELISA.

$\operatorname{PrP}^{\mathrm{C}}$ in different tissues was detected reliably using the sELISA method. The quantification test was calibrated using a linear standard curve detecting recombinant bovine PrP (Fig. 1). Based on Equation (i), using this assay, the LD value of bovine PrP was derived and recorded as $0.1651 \mathrm{ng}$ (bovine PrP) per $100 \mu \mathrm{l}$. Of the tissue PrP contents observed using this assay (Fig. 2), the highest level was detected in the brain $(13.3 \mu \mathrm{g} / \mathrm{g}$ tissue), followed by the longissimus capitis muscle (2.62 $\mu \mathrm{g} / \mathrm{g}$ tissue; 5.2-fold less than the brain), iliocostalis thoracis muscle $(2.53 \mu \mathrm{g} / \mathrm{g}$ tissue), splenius muscle $(2.44 \mu \mathrm{g} / \mathrm{g}$ tissue), biceps femoris muscle (2.09 $\mu \mathrm{g} / \mathrm{g}$ tissue), triceps brachii muscle (1.85 $\mu \mathrm{g} / \mathrm{g}$ tissue), longissimus thoracis muscle (1.66 $\mu \mathrm{g} / \mathrm{g}$ tissue), ileum (1.43 $\mu \mathrm{g} / \mathrm{g}$ tissue), jejunum $(1.41 \mu \mathrm{g} / \mathrm{g}$ tissue), duodenum (1.37 $\mu \mathrm{g} / \mathrm{g}$ tissue), colon (1.33 $\mu \mathrm{g} / \mathrm{g}$ tissue),

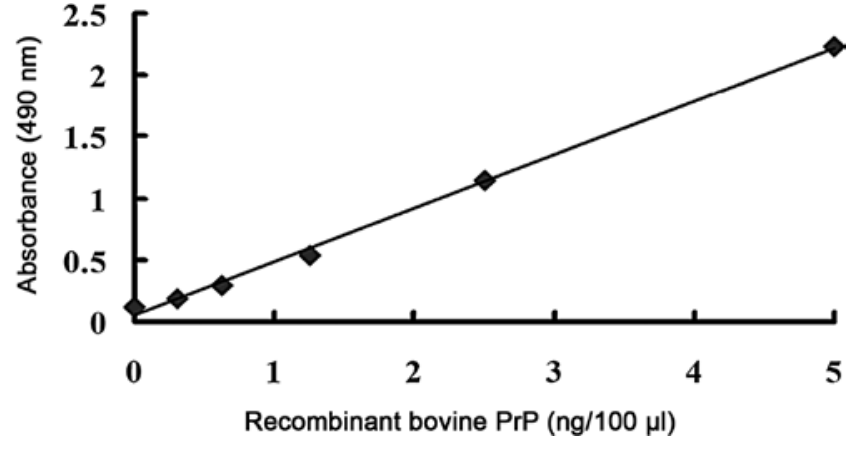

Figure 1. ELISA standard curve derived from the absorbance $(490 \mathrm{~nm})$ of recombinant bovine prion protein $(\mathrm{PrP})$ in $\mathrm{ng} / 100 \mu \mathrm{l}$. The ELISA standard curve was derived from recombinant bovine PrP, which was detected by the sandwich ELISA method with T2 and T17-HRP antibodies for quantitative determinations of $\mathrm{PrP}^{\mathrm{C}}$ in bovine tissues. Each value is the mean of triplicate determinations.

cecum $(1.20 \mu \mathrm{g} / \mathrm{g}$ tissue), apex linguae (1.12 $\mu \mathrm{g} / \mathrm{g}$ tissue), omotransversarius muscle $(0.91 \mu \mathrm{g} / \mathrm{g}$ tissue), posterior part of the corpus linguae $(0.89 \mu \mathrm{g} / \mathrm{g}$ tissue), anterior part of the corpus linguae $(0.83 \mu \mathrm{g} / \mathrm{g}$ tissue $)$, radix linguae $(0.75 \mu \mathrm{g} / \mathrm{g}$ tissue) and liver (0.25 $\mu \mathrm{g} / \mathrm{g}$ tissue) (Fig. 2A). In the tongue, the PrP content was higher at the apex than at the root, while the ileum was found to manifest the highest $\operatorname{PrP}^{\mathrm{C}}$ content in the intestines. Values for each tissue in the prion protein-deficient cows were quite low (Fig. 2B); these values were therefore judged to be background levels. A previous report indicated that Western blotting tests of the brain and spleen from prion protein-deficient cows were negative (23).

$\mathrm{PgP}$ 9.5-positive nerve cells and $\mathrm{T}$ 2-positive $\mathrm{PrP}^{\mathrm{C}}$ were detected in the plexuses of the jejunum (Fig. 3A, C and E) and ileum (Fig. 3B, D and F). The distributions of $\mathrm{PrP}^{\mathrm{C}}$ were almost consistent with those of the nerve cells. $\mathrm{PrP}^{\mathrm{C}}$ was expressed on the cell surface of nerve cells (Fig. 3B, D and F). sELISA indicated the presence of substantial amounts of neural tissue in most of the intestinal tissues (Fig. 2A).

\section{Discussion}

$\mathrm{PrP}^{\mathrm{C}}$ expression is necessary for the development of TSEs $(27,28)$. The chronological and spatial transport of $\mathrm{PrP}^{\mathrm{Sc}}$ after oral infection remains unclear. After oral challenge, $\mathrm{PrP}^{\mathrm{Sc}}$ is detected in frontline tissues such as the gastrointestinal tract and its associated lymphoreticular system in sheep, mice and hamsters; i.e., tissues that are highly susceptible to infection (29-35). $\operatorname{PrPC}^{\mathrm{C}}$ is the substrate for the formation of pathologyassociated conformer $\mathrm{PrP}^{\mathrm{Sc}}$ (36). However, studies on $\mathrm{PrP}^{\mathrm{C}}$ distribution in cattle are limited (37-39). Although quantitative studies of $\mathrm{PrP}^{\mathrm{C}}$ expression at the protein level have been documented in sheep, none have been attempted in cattle.

This study first labeled anti-PrP mAbs (purified from T2 and T17 hybridoma supernatants) with HRP before quantitative assessments with a novel sELISA method using these $\mathrm{mAbs}$. $\operatorname{PrP}^{\mathrm{C}}$ content in the peripheral tissues of cattle was then determined by the sELISA method. This sELISA system was able to detect PrP in both hamsters and cattle (data not shown). Moudjou et al reported that $\operatorname{PrP}^{\mathrm{C}}$ content in sheep depends on the prion protein gene (PRNP) genotype (20). Moreover, according to Nakamura et al, certain polymorphisms of the 
A

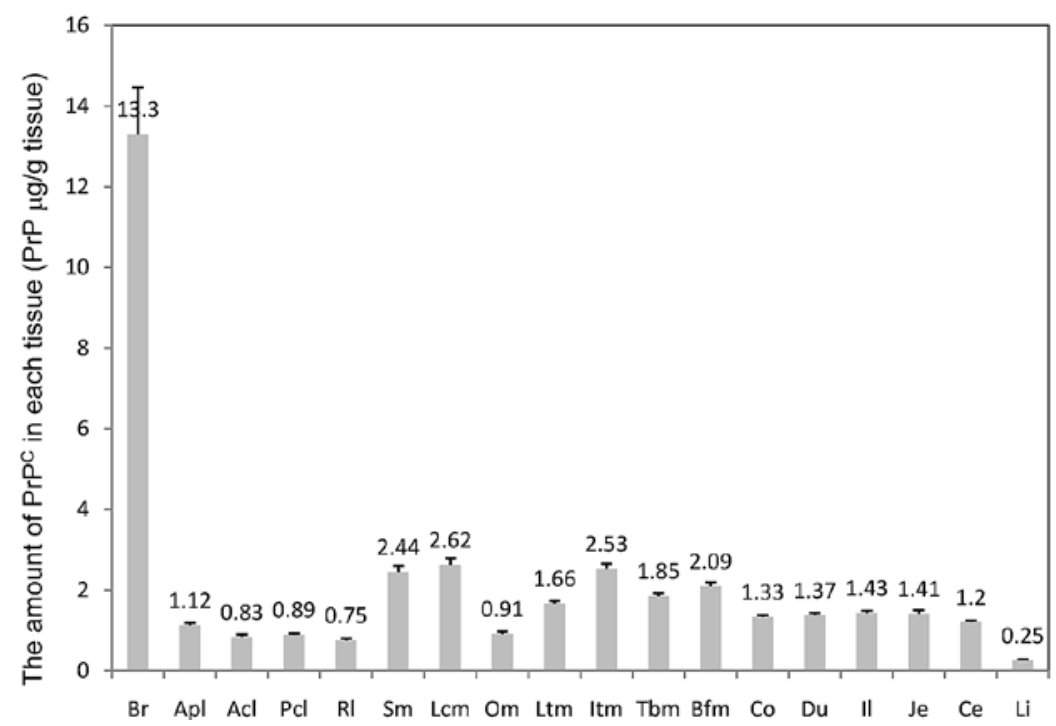

B

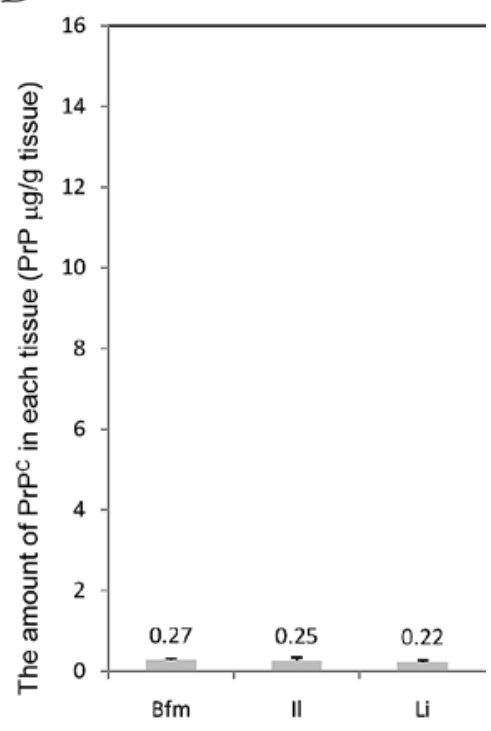

Figure 2. Quantitative determinations of the bovine cellular isoform of prion protein $\left(\operatorname{PrP}^{\mathrm{C}}\right)$ in peripheral tissues/organs. The estimated content of the cellular isoform of prion protein $\left(\mathrm{PrP}^{\mathrm{C}}\right)$ in bovine tissues $(\mathrm{A})$ and prion protein-deficient cows $(\mathrm{B})$ by the sandwich ELISA are expressed as $\mu \mathrm{g}$ protein/g of tissue. Tissues tested included the brain $(\mathrm{Br})$, apex linguae (Apl), anterior part of the corpus linguae (Acl), posterior part of the corpus linguae (Pcl), radix linguae (Rl), splenius muscle $(\mathrm{Sm})$, longissimus capitis muscle $(\mathrm{Lcm})$, omotransversarius muscle $(\mathrm{Om})$, longissimus thoracis muscle $(\mathrm{Ltm})$, iliocostalis thoracis muscle (Itm), triceps brachii muscle (Tbm), biceps femoris muscle (Bfm), colon (Co), duodenum (Du), ileum (Il), jejunum (Je) cecum (Ce) and liver (Li). Each value represents the mean of triplicate determinations. Vertical error bars represent the standard deviations.
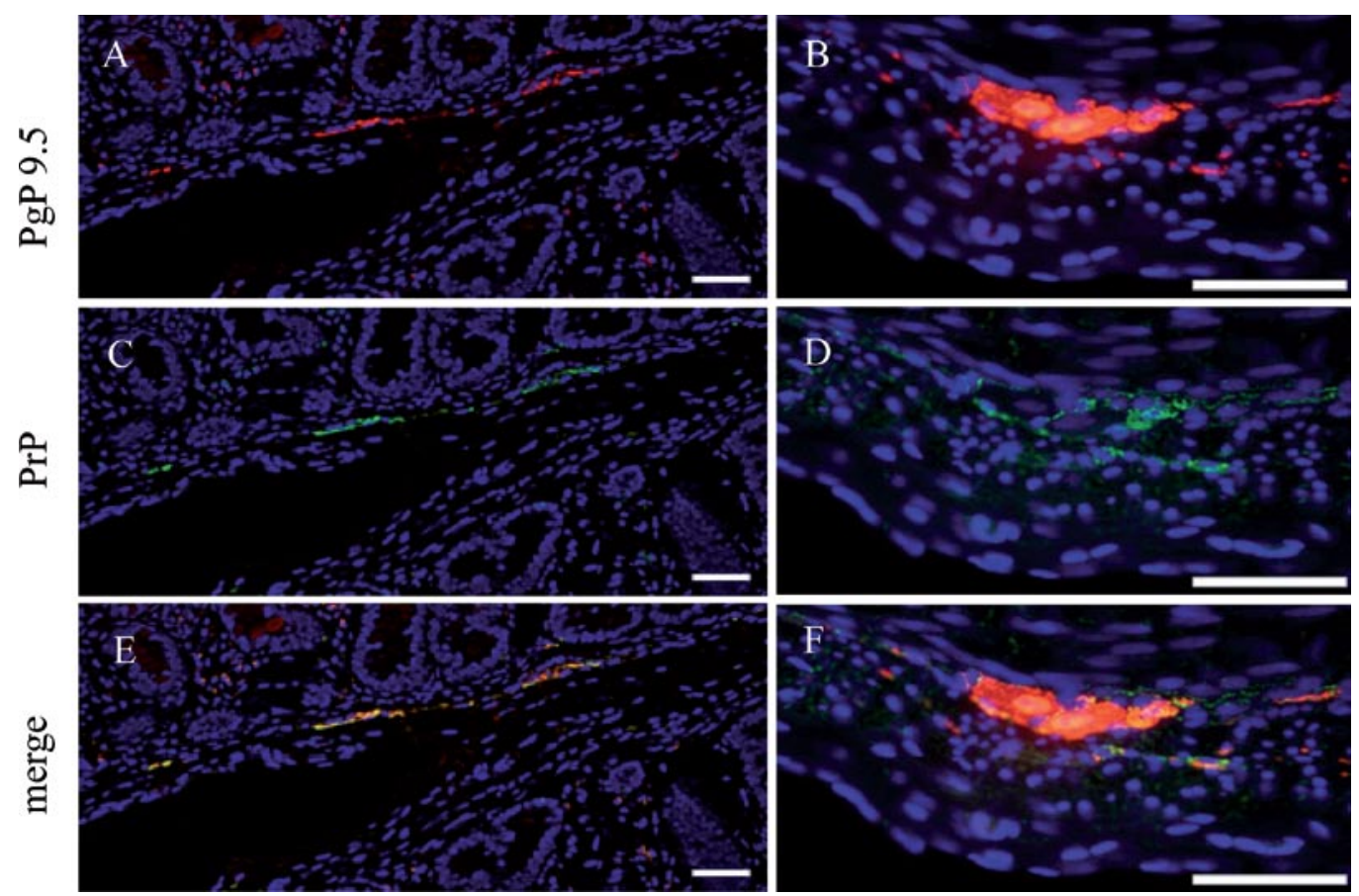

Figure 3. Immunohistochemical detection of the cellular isoform of prion protein $\left(\mathrm{PrP}^{\mathrm{C}}\right)$ in plexuses of jejunum and ileum. (A and B) Substantial areas reacted with the PgP 9.5 antibody staining (red). (C and D) Substantial areas reacted with the T2 antibody staining (green). (E and F) Merged images of PgP 9.5 and T2 reactions. Bar, $50 \mu \mathrm{m}$.

bovine PRNP promoter region in Japanese Black cattle influence promoter activity (40). Therefore, it is necessary to study $\operatorname{PrP}^{\mathrm{C}}$ content in the bovine tissues of various PRNP genotypes. The novel quantitative method used in the determination of the $\operatorname{PrP}^{\mathrm{C}}$ content of various tissues in single cattle in this study facilitates an understanding of protein levels, which it was previously impractical to measure. This is the first study to reliably and quantitatively assay $\operatorname{PrP}^{\mathrm{C}}$ contents in cattle.

An understanding of the distribution and expression level of $\mathrm{PrP}^{\mathrm{C}}$ is important, as host-encoded $\mathrm{PrP}^{\mathrm{C}}$ is required for the conversion to $\mathrm{PrP}^{\mathrm{Sc}}$. In addition, both the route and rate of $\mathrm{PrP}^{\mathrm{Sc}}$ transport are controlled by the expression level of host- 
encoded $\operatorname{PrP}^{\mathrm{C}}$ (41,42). Using immunohistochemistry, we previously examined nerve distribution in the same tissues of the cattle used in the present study (43). The distribution of $\operatorname{PrP}^{\mathrm{C}}$ is not always consistent with that of nerve cells. In conclusion, this study highlights the risk associated with bovine tongue, skeletal muscles and intestines as commercial products and the presence of $\operatorname{PrP}^{\mathrm{C}}$ (a protein that has the potential to form $\left.\operatorname{PrP}^{\mathrm{Sc}}\right)$. To date, it has been impractical to quantitatively determine $\mathrm{PrP}^{\mathrm{C}}$ levels. However, with the novel sELISA method employed in this study, $\operatorname{PrP}^{\mathrm{C}}$ was detected in these tissues/ organs. The presence of $\operatorname{PrP}^{\mathrm{C}}$ in bovine ileum tissue was previously reported using immnunohistochemistry (44). However, the authors did not demonstrate the amount of $\operatorname{PrP}^{\mathrm{C}}$ using sELISA or Western blotting. Another report by Iwata et al revealed $\mathrm{PrP}^{\mathrm{Sc}}$ distribution in the ileum of BSE cases using Western blotting (45), but failed to detect $\operatorname{PrP}^{\mathrm{C}}$ in bovine ileum tissues. Currently, sELISA and immunohistochemistry are the available methods used to evaluate $\operatorname{PrP}^{\mathrm{C}}$ content in ileum tissue.

In the present study, it was additionally revealed that tissues from cattle lacking prion protein are suitable for use as a negative control for the risk analysis of prion disease. We also investigated the distribution of $\operatorname{PrP}^{\mathrm{C}}$ in 2-week-old cows. The distribution pattern was found to be the same (data not shown). The availability of a qualitative and quantitative approach using the present novel sELISA method may facilitate the in-depth assessment of the risks of $\operatorname{PrP}^{\mathrm{Sc}}$ accumulation in the peripheral tissues of cattle.

\section{Acknowledgements}

This study was supported in part by Grants-in-Aid from the Food Safety Commission of Japan, the Ministry of Agriculture, Forestry and Fisheries of Japan, and the Ministry of Education, Science, Culture and Technology of Japan. We thank Dr Anthony Foong for comments on the manuscript. We thank Dr Yutaka Sendai, Central Research Institute for Feed and Livestock, ZEN-NOH, and Drs Yoshito Aoyagi and Manami Urakawa, ET Center, ZEN-NOH for providing the prion protein-deficient cattle.

\section{References}

1. Prusiner SB: Prions. Proc Natl Acad Sci USA 95: 13363-13383, 1998.

2. Jackson GS and Clarke AR: Mammalian prion proteins. Current Opini Struct Biol 10: 69-74, 2000.

3. Sakudo A, Onodera T, Suganuma Y, Kobayashi T, Saeki K and Ikuta K: Recent advances in clarifying prion protein functions using knockout mice and derived cell lines. Mini Rev Med Chem 87: 589-601, 2006.

4. Andréoletti O, Simon S, Lacroux C, et al: PrPSc accumulation in myocytes from sheep incubating natural scrapie. Nat Med 10: 591-593, 2004

5. Casalone C, Corona C, Crescio MI, Martucci F, Mazza M, Ru G, Bozzetta E, Acutis PL and Caramelli M: Pathological prion protein in the tongues of sheep infected with naturally occurring scrapie. J Virol 79: 5847-5849, 2005.

6. Bosque PJ, Ryou C, Telling G, Peretz D, Legname G, DeArmond SJ and Prusiner SB: Prions in skeletal muscle. Proc Natl Acad Sci USA 99: 3812-3817, 2002.

7. Masujin K, Mathews D, Wells GA, Mohri S and Yokoyama T: Prions in the peripheral nerves of bovine spongiform encephalopathy-affected cattle. J Gen Virol 88: 1850-1858, 2007.

8. Thomzig A, Cardone F, Krüger D, Pocchiari M, Brown P and Beekes M: Pathological prion protein in muscles of hamsters and mice infected with rodent-adapted BSE or vCJD. J Gen Virol 87: 251-254, 2006.
9. Bartz JC, Kincaid AE and Bessen RA: Rapid prion neuroinvasion following tongue infection. J Virol 77: 583-591, 2003.

10. Thomzig A, Kratzel C, Lenz G, Kruger D and Beekes M: Widespread PrPSc accumulation in muscles of hamsters orally infected with scrapie. EMBO Rep 4: 530-533, 2003.

11. Thomzig A, Schulz-Schaeffer W, Kratzel C, Mai J and Beekes M: Preclinical deposition of pathological prion protein PrPSc in muscles of hamsters orally exposed to scrapie. J Clin Invest 113: 1465-1472, 2004.

12. Mulcahy ER, Bartz JC, Kincaid AE and Bessen RA: Prion infection of skeletal muscle cells and papillae in the tongue. $\mathrm{J}$ Virol 78: 6792-6798, 2004.

13. Glatzel M, Abela E, Maissen M and Aguzzi A: Extraneural pathologic prion protein in sporadic Creutzfeldt-Jakob disease. N Engl J Med 349: 1812-1820, 2003.

14. Kovacs GG, Lindeck-Pozza E, Chimelli L, Araújo AQC, Gabbai AA, Ströbel T, Glatzel M, Aguzzi A, Budka H: Creutzfeldt-Jakob disease and inclusion body myositis: abundant disease-associated prion protein in muscle. Ann Neurol 55: 121-125, 2004.

15. Brown KL, Ritchie DL, McBride PA and Bruce ME: Detection of PrP in extraneural tissues. Microsc Res Tech 50: 40-45, 2000.

16. Fournier JG, Escaig-Haye F, Billette de Villemeur T, Robain O, Lasmezas CI, Deslys JP, Dormont D and Brown P: Distribution and submicroscopic immunogold localization of cellular prion protein (PrPC) in extracerebral tissues. Cell Tissue Res 292: 77-84, 1998.

17. Ford M, Li H, Burton L, Jen A, Morris R and Hall S: Cellular prion protein expression in the mouse. Eur J Neurosci 12: 116, 2000.

18. Ford MJ, Burton LJ, Morris RJ and Hall SM: Selective expression of prion protein in peripheral tissues of the adult mouse. Neuroscience 113: 177-192, 2002.

19. Horiuchi M, Yamazaki N, Ikeda T, Ishiguro N and Shinagawa M: A cellular form of prion protein (PrPC) exists in many nonneuronal tissues of sheep. J Gen Virol 76: 2583-2587, 1995.

20. Moudjou M, Frobert Y, Grassi J and La Bonnardière C: Cellular prion protein status in sheep: tissue-specific biochemical signatures. J Gen Virol 82: 2017-2024, 2001.

21. Peters J, Miller JM, Jenny AL, Peterson TL and Carmichael KP: Immunohistochemical diagnosis of chronic wasting disease in preclinically affected elk from a captive herd. J Vet Diagn Invest 12: 579-582, 2000.

22. Pammer J, Suchy A, Rendl M and Tschachler E: Cellular prion protein expressed by bovine squamous epithelia of skin and upper gastrointestinal tract. Lancet 354: 1702-1703, 1999.

23. Richt JA, Kasinathan P, Hamir AN, Castilla J, Sathiyaseelan T, Vargas F, Sathiyaseelan J, Wu H, Matsushita H, Koster J, Kato S, Ishida I, Soto C, Robl JM and Kuroiwa Y: Production of cattle lacking prion protein. Nat Biotechnol 25: 132-138, 2007.

24. Ano Y, Nakayama H, Sakai Y, Sakudo A, Endo M, Ebisu S, Li JY, Uetsuka K, Manabe $\mathrm{N}$ and Onodera T: Incorporation of B-amyloid protein through the ileal epithelium before and after weaning: Model for orally transmitted amyloidoses. Microbiol Immunol 52: 429-434, 2008.

25. Ano Y, Nakayama H, Sakudo A, Sawano Y, Tanokura M, Itohara S and Onodera T: Intestinal uptake of amyloid B protein through columnar epithelial cells in suckling mice. Histol Histopathol 24: 283-292, 2009.

26. Miller JN and Miller JC: Statistics and Chemometrics for Analytical Chemistry. 4th edition. Prentice Hall, Harlow, UK, 2000.

27. Bueler HR, Aguzzi A, Sailer A, Greiner RA, Autenried P, Aguet M and Weissmann C: Mice devoid of PrP are resistant to scrapie. Cell 73: 1339-1347, 1993.

28. Prusiner SB, Groth D, Serban A, Koehler R, Foster D, Torchia M, Burton D, Yang SL and DeArmond SJ: Ablation of the prion protein (PrP) gene in mice prevents scrapie and facilitates production of anti-PrP antibodies. Proc Natl Acad Sci USA 90: 10608-10612, 1993.

29. McKinley MP, Bolton DC and Prusiner SB: A proteaseresistant protein is a structural component of the scrapie prion. Cell 35: 57-62, 1983.

30. Race R, Jenny A and Sutton D: Scrapie infectivity and proteinase K-resistant prion protein in sheep placenta, brain, spleen, and lymph node: implications for transmission and antemortem diagnosis. J Infect Dis 178: 949-953, 1998.

31. Van Keulen LJM, Schreuder BEC, Vromans MEW, Langeveld JP and Smits MA: Scrapie-associated prion protein in the gastrointestinal tract of sheep with natural scrapie. J Comp Pathol 121: $55-63,1999$. 
32. Bons N, Mestre-Rances N, Belli P, Cathala F, Gajdusek DC and Brown P: Natural and experimental infection of nonhuman primates by bovine spongiform encephalopathy agents. Proc Natl Acad Sci USA 96: 4046-4051, 1999.

33. Maignien T, Lasmezas CI, Beringue V, Dormont D and Deslys JP: Pathogenesis of the oral route of infection of mice with scrapie and bovine spongiform encephalopathy agents. J Gen Virol 80: 3035-3042, 1999.

34. Beekes M and McBride PA: Early accumulation of pathological $\mathrm{PrP}$ in the enteric nervous system and gut-associated lymphoid tissue of hamsters orally infected with scrapie. Neurosci Lett 278 : 181-184, 2000

35. Andréoletti O, Berthon P, Marc D, Sarradin P, Grosclaude J, van Keulen L, Schelcher F, Elsen JM and Lantier F: Early accumulation of $\mathrm{PrP}^{\mathrm{Sc}}$ in gut-associated lymphoid and nervous tissues of susceptible sheep from a Romanov flock with natural scrapie. J Gen Virol 81: 3115-3126, 2000.

36. Weissmann C: Molecular biology of transmissible spongiform encephalopathies. FEBS Lett 389: 3-11, 1996.

37. Amselgruber WM, Büttner M, Schlegel T, Schweiger M and Pfaff E: The nomal cellular prion protein $\left(\mathrm{PrP}^{\mathrm{C}}\right)$ is strongly expressed in bovine endocrine pancreas. Histochem Cell Biol 125: 441-448, 2006.

38. Didier A, Dietrich R, Steffl M, Gareis M, Groschup MH, MullerHellwig S, Martlbauer E and Amselgruber WM: Cellular prion protein in the bovine mammary is selectively expressed in active lactocytes. J Histochem Cytochem 54: 1255-1261, 2006.

39. Marcos Z, Bodegas ME, Sesma MP and Guembe L: Comparative study of $\mathrm{PrP}^{\mathrm{C}}$ expression in rat, monkey, and cow gastrointestinal tract. Ann NY Acad Sci 1040: 391-394, 2005.
40. Nakamura I, Xue G, Sakudo A, Saeki K, Matsumoto Y, Ikuta K and Onodera T: Novel single nucleotide polymorphisms in the specific protein 1 binding site of the bovine PRNP promoter in Japanese Black cattle: Impairment of its promoter activity. Intervirology 50: 190-196, 2007.

41. Blättler T, Brandner S, Raeber AJ, Klein MA, Voiglander T, Weissmann $\mathrm{C}$ and Aguzzi A: PrP-expressing tissue required for transfer of scrapie infectivity from spleen to brain. Nature 389 : $69-73,1997$.

42. Glatzel $\mathrm{M}$ and Aguzzi A: $\operatorname{Pr} \mathrm{P}(\mathrm{C})$ expression in the peripheral nervous system is a determinant of prion neuroinvasion. J Gen Virol 81: 2813-2821, 2000.

43. Zhu X, Matoba S, Hara K, Ano Y, Kobayashi S, Tsunekawa N, Kanai Y, Manabe N, Onodera T and Kurohmaru M: Ratio of peripheral nervous tissues in tongues, skeletal muscles and intestines in cows. Okajima Folia Anat Jpn 85: 73-77, 2008.

44. Miyazawa K, Kanaya T, Tanaka S, Takakura I, Watanabe K, Ohwada S, Kitazawa H, Rose MT, Sakaguchi S, Katamine S, Yamaguchi T and Aso H: Immunohistochemical characterization of cell types expressing the cellular prion protein in the small intestine of cattle and mice. Histochem Cell Biol 127: 291-301, 2007.

45. Iwata N, Sato Y, Higuchi Y, Nohtomi K, Nagata N, Hasegawa $H$, Tobiume M, Nakamura Y, Hagiwara K, Fruoka H, Horiuchi M, Yamakawa Y and Sata T: Distribution of $\operatorname{PrP}^{\mathrm{Sc}}$ in cattle with bovine spongiform encephalopathy slaughtered at abattoirs in Japan. Jpn J Infect Dis 59: 100-107, 2006. 